\title{
CALD1 wt Allele
}

National Cancer Institute

\section{Source}

National Cancer Institute. CALD1 wt Allele. NCI Thesaurus. Code C113325.

Human CALD1 wild-type allele is located in the vicinity of $7 q 33$ and is approximately 226 $\mathrm{kb}$ in length. This allele, which encodes caldesmon protein, plays a role in actin filament stability. 